\title{
Therapeutic waters as geotourism values of the Polish Baltic sea coast
}

Wody lecznicze jako walory geoturystyczne polskiego wybrzeża Bałtyku

\section{Arkadiusz Krawiec}

Nicolaus Copernicus University, Department of Geology and Hydrogeology, ul.Lwowska 1,87-100 Toruń,e-mail: arkadiusz.krawiec@umk.pl
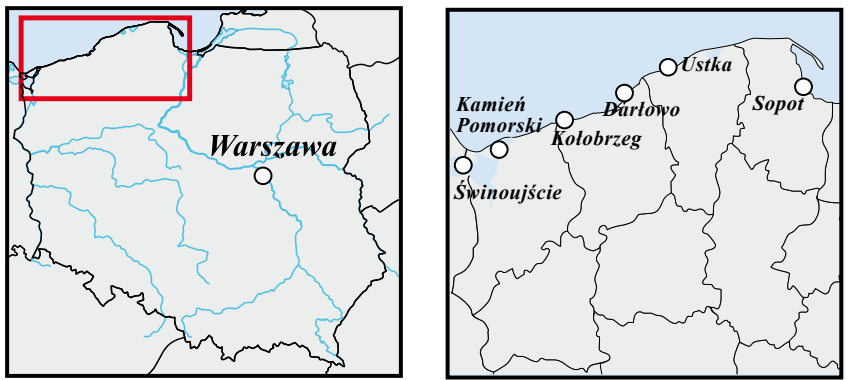

Abstract: The oldest spa towns in the Polish Lowland have developed on the basis of brines from which salt used to be refined. This article presents conditions for the occurrence of medicinal (therapeutic) waters on the Polish Baltic Sea coast. It discusses the development of naturopathy in the area and presents brine water intakes and their utilisation. Moreover, the main tourist attractions of the spa towns and chances for the development of health tourism in the area are enumerated.

Keywords: therapeutic waters, geotourism values, health resort, Baltic coast area

Treść: Najstarsze uzdrowiska na Niżu Polskim powstaty $w$ miejscach, gdzie występujq solanki, z których warzono sól. $W$ artykule przedstawiono warunki występowania wód leczniczych na polskim wybrzeżu Bałtyku. Omówiono rozwój przyrodolecznictwa na tym obszarze, scharakteryzowano ujęcia wód solankowych $i$ wykorzystanie zasobów tych wód. Zaprezentowano główne walory turystyczne uzdrowisk oraz przedstawiono możliwość rozwoju na tym obszarze turystyki uzdrowiskowej.

Stowa kluczowe: wody lecznicze, walory geoturystyczne, uzdrowisko, wybrzeże Battyku

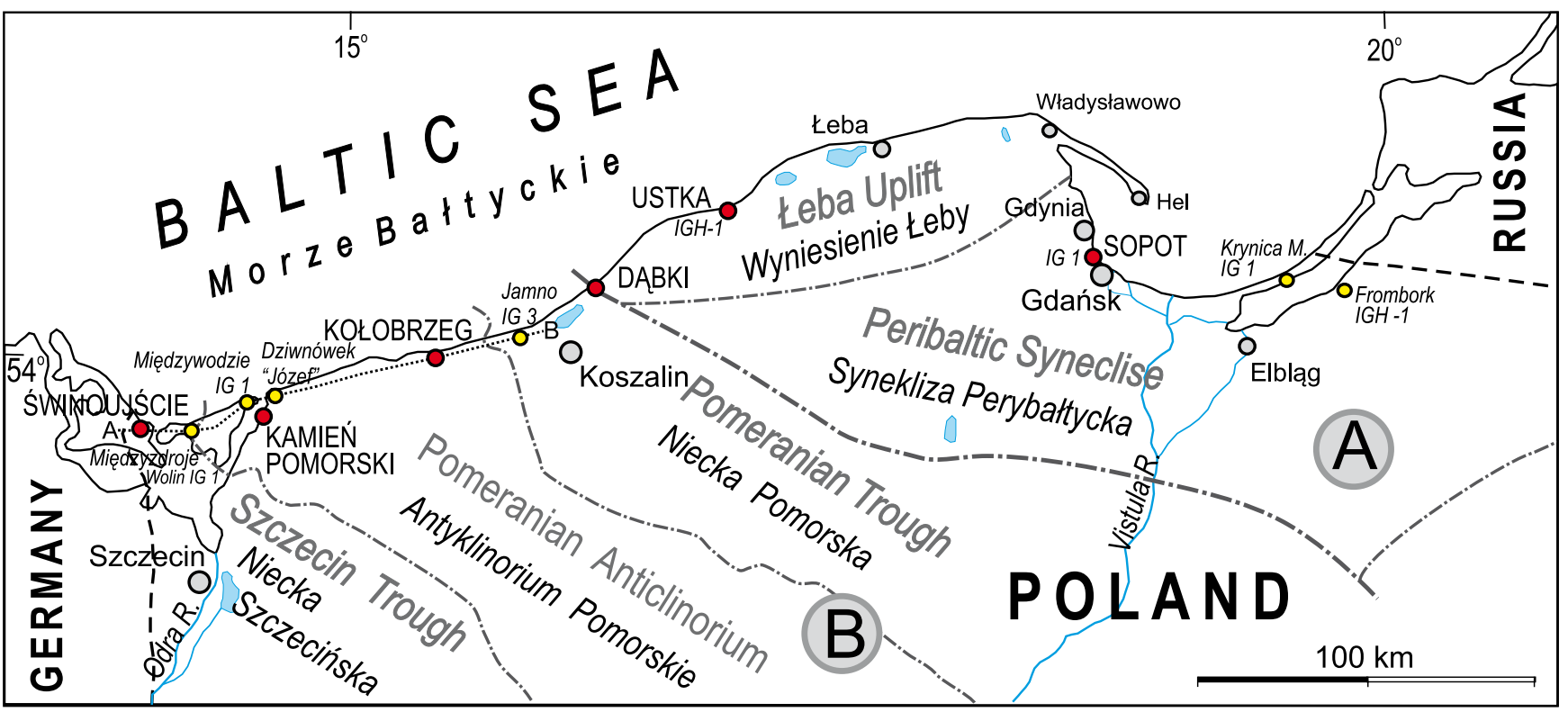
KAMIEŃ
health resorts
POMORSKI
uzdrowiska statutowe
$0^{\text {Jamno IG } 3}$
deposits of therapeutic waters
miejsca występowania wód leczniczych i termalnych

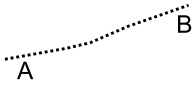
hydrogeological cross-section line linia przekroju hydrogeologicznego

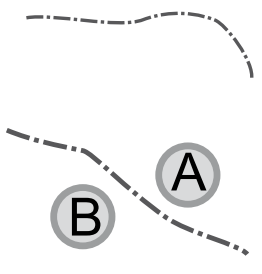

boundary geological units granice jednostek geologicznych

boundary provinces granice prowincji

A - Precambrian platform Platforma prekambryjska

B - Paleozoic platform Platforma paleozoiczna

Fig. 1. Location of spa towns on the Polish Baltic Sea coast • Położenie uzdrowisk na polskim wybrzeżu Morza Bałtyckiego 


\section{Introduction}

In Poland there are 44 towns having the spa status. Six of them are located in the coastal area of the Baltic Sea. These are: Świnoujście, Kamień Pomorski, Kołobrzeg and
Dąbi located in the West Pomeranian Voivodeship as well as Ustka and Sopot in the Pomeranian Voivodeship (Fig. 1). Their emergence and location were influenced by the presence of natural medicinal resources (brine, therapeutic peat), and healing properties of the maritime climate.

Tab. 1. Classification of therapeutic groundwaters based on their pharmaco-dynamic factors. In shadow minimal concentration or temperature required for therapeutic water (Ciężkowski et al., 2010; Rozporządzenie..., 2006) • Klasyfikacja wód leczniczych podziemnych na podstawie czynników farmakodynamicznych. W szarym tle minimalne stężenia lub temperatura wymagana dla wody leczniczej (Ciężkowski $i$ in., 2010; Rozporządzenie..., 2006)

\begin{tabular}{|c|c|c|c|}
\hline $\begin{array}{l}\text { Total Dissolved Solids (TDS) } \\
\text { mineralizacja }\end{array}$ & \multicolumn{2}{|c|}{$\begin{array}{l}\text { Pharmaco-dynamic factors - specific components } \\
\text { współczynniki farmakodynamiczne - składniki swoiste }\end{array}$} & $\begin{array}{l}\text { Temperature } \\
\text { temperatura }\end{array}$ \\
\hline$\geq 1 \mathrm{~g} / \mathrm{dm}^{3}$ & $\begin{array}{l}2 \mathrm{mg} \mathrm{F}- \\
1 \mathrm{mg} \mathrm{l}- \\
1 \mathrm{mg} \mathrm{S}(\mathrm{II}) \\
70 \mathrm{mg} \mathrm{H}_{2} \mathrm{SiO}_{3}\end{array}$ & $\begin{array}{l}\text { fluoride water / woda fluorkowa } \\
\text { iodide water / woda jodkowa } \\
\text { sulphide water / woda siarczkowa } \\
\text { silica water / woda krzemowa }\end{array}$ & $\begin{array}{l}>20^{\circ} \mathrm{C} \text { thermal water } \\
\text { / woda termalna }\end{array}$ \\
\hline$<1 \mathrm{~g} / \mathrm{dm}^{3}$ & $\begin{array}{l}10 \mathrm{mg} \mathrm{Fe}(\mathrm{II}) \\
74 \mathrm{~Bq} \\
250 \mathrm{mg} \text { free } \mathrm{CO}_{2} \\
1000 \mathrm{mg} \text { free } \mathrm{CO}_{2}\end{array}$ & $\begin{array}{l}\text { ferruginous water / woda żelazista } \\
\text { radon or radioactive water / woda radonowa } \\
\text { carbonated water / woda kwasowęglowa } \\
\mathrm{CO}_{2} \text {-rich water, carbonated water / szczawa }\end{array}$ & $\begin{array}{c}<20^{\circ} \mathrm{C} \\
\text { cold water } \\
\text { / woda chłodna }\end{array}$ \\
\hline
\end{tabular}

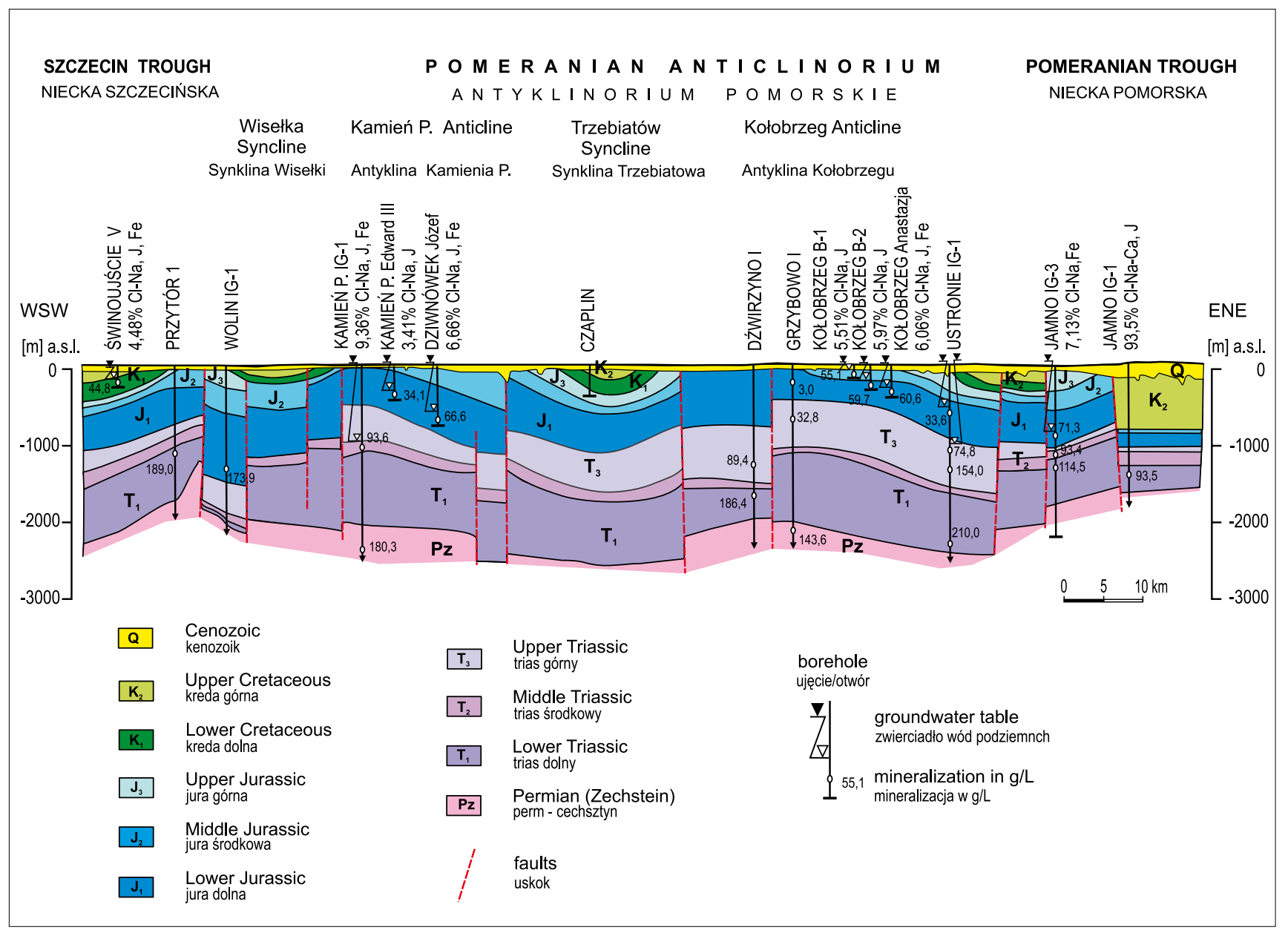

Fig. 2. Hydrogeological cross-section (modified and supplemented after Kaczor, 2005) • Przekrój hydrogeologiczny (zmieniony i uzupełniony na podstawie Kaczor, 2005) 


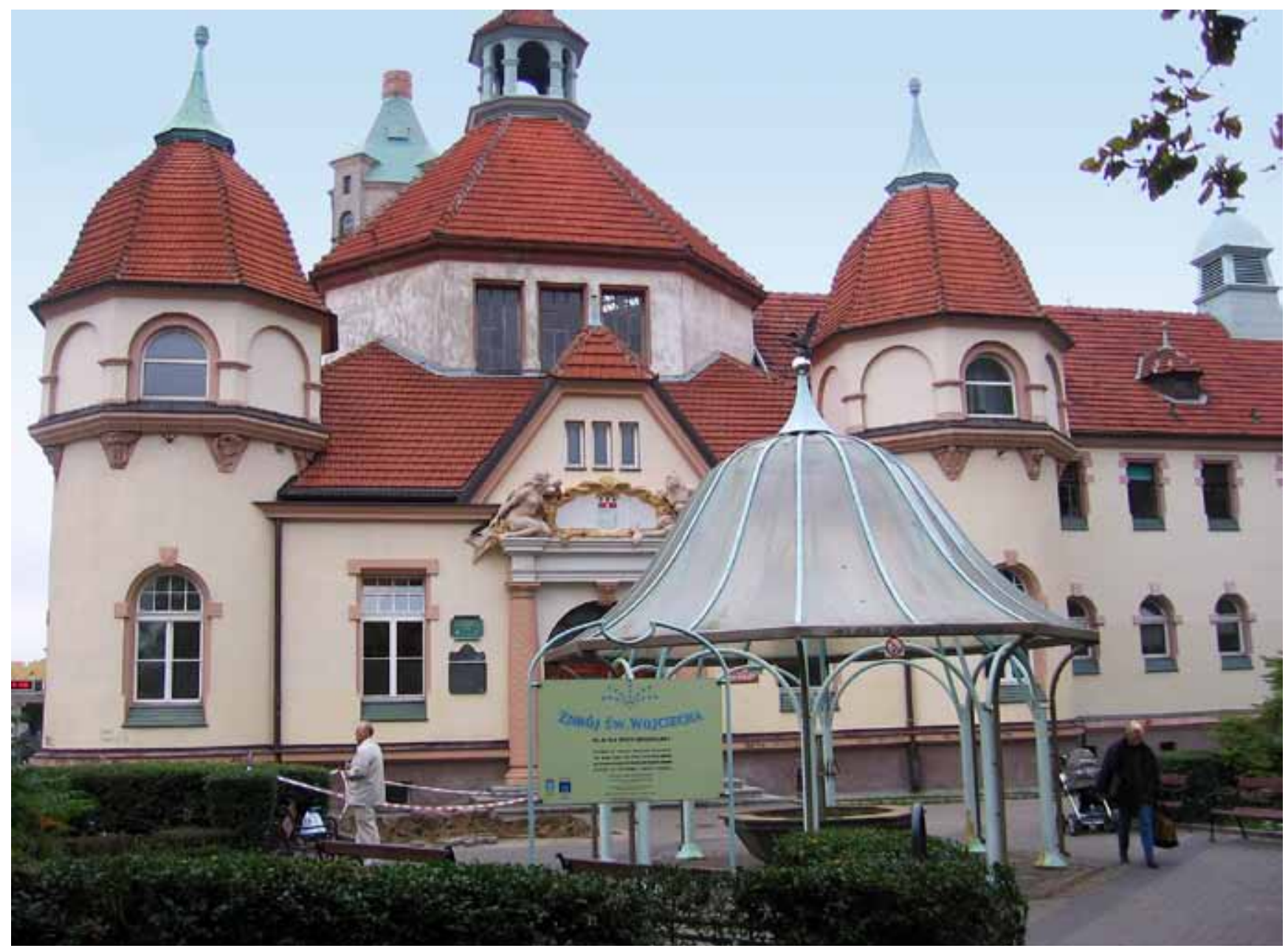

In Poland, therapeutic water is groundwater which is not contaminated chemically or microbiologically, shows natural variability in terms of physical and chemical properties, and meets at least one of the conditions relating to mineralisation, temperature, or contents of specific components (Tab. 1). Each mineral water (of mineralisation $\geq 1 \mathrm{~g} / \mathrm{dm}^{3}$ ) can be medicinal water, regardless of whether it contains specific components. Moreover, weakly mineralised water can be regarded as healing if it contains at least one specific component and/or has a temperature above $20^{\circ} \mathrm{C}$ (Rozporządzenie..., 2006).

Brines include water of overall mineralisation at least 35 $\mathrm{g} / \mathrm{dm}^{3}$, whose main components are chloride, sodium and calcium ions. The largest resources of these waters in Poland are located in the Polish Lowlands. These waters are well recognised and examined chemically. Brines are commonly used in balneology in most health resorts located in the Polish Lowlands.

The earliest spa towns in the Polish Lowlands, unlike health resorts in the Carpathians and in the Sudetes where the basis of their origin and development were natural springs of mineral waters used for therapeutic purposes, developed on the basis of brines, from which for over 1,000 years salt was refined (Kolago, 1964; Dowgiałło, 1965). Brines of the Cl-Na type are now extracted primarily through boreholes. Specific components, which have pharmacodynamic properties, predominantly include iodides and occasionally iron.
Fig. 3. St. Adalbert's spring in Sopot, phot. A. Krawiec • Zdrój Świętego Wojciecha w Sopocie, fot. A. Krawiec

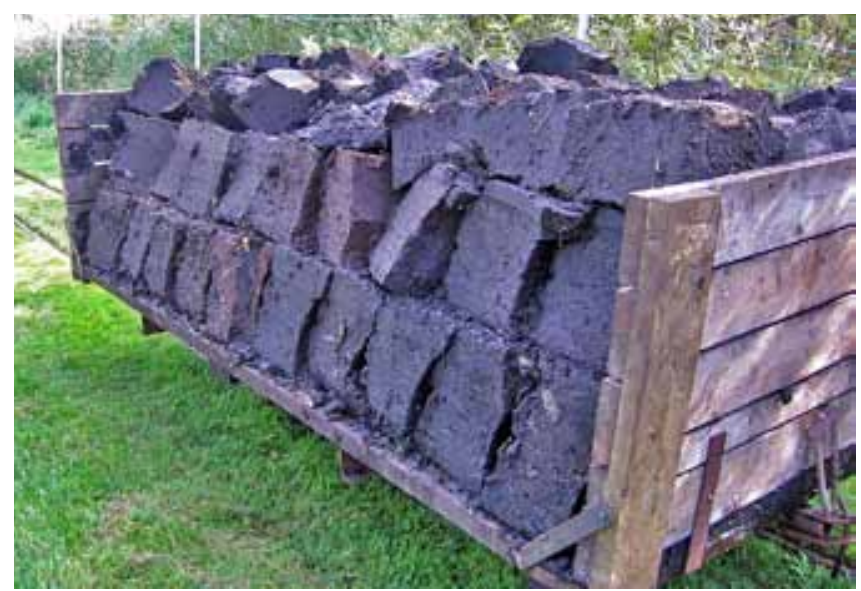

Fig. 4. Extraction of therapeutic peat in Kołobrzeg, phot. A. Krawiec - Wydobywanie torfu leczniczego (borowiny) w Kołobrzegu, fot. A. Krawiec

This paper presents conditions for the occurrence of therapeutic waters on the Polish Baltic Sea coast. It discusses the development of naturopathy in the area and presents brine water intakes, and their utilisation. Moreover, the main tourist attractions of the spa towns and chances for the development of health tourism in the area are enumerated. 


\section{Geology and hydrogeology}

The Polish Baltic Sea coast is located in the Polish Lowland where therapeutic and thermal springs occur within two large regions, namely the province of the Paleozoic platform and the province of the Precambrian platform (Paczyński, Płochniewski, 1996). Mineral waters in the analysed area are at different depths. Waters considered as therapeutic have mainly been found in Cretaceous, Jurassic and Triassic deposits (Fig. 2). Mineral waters are also common in older aquifers.

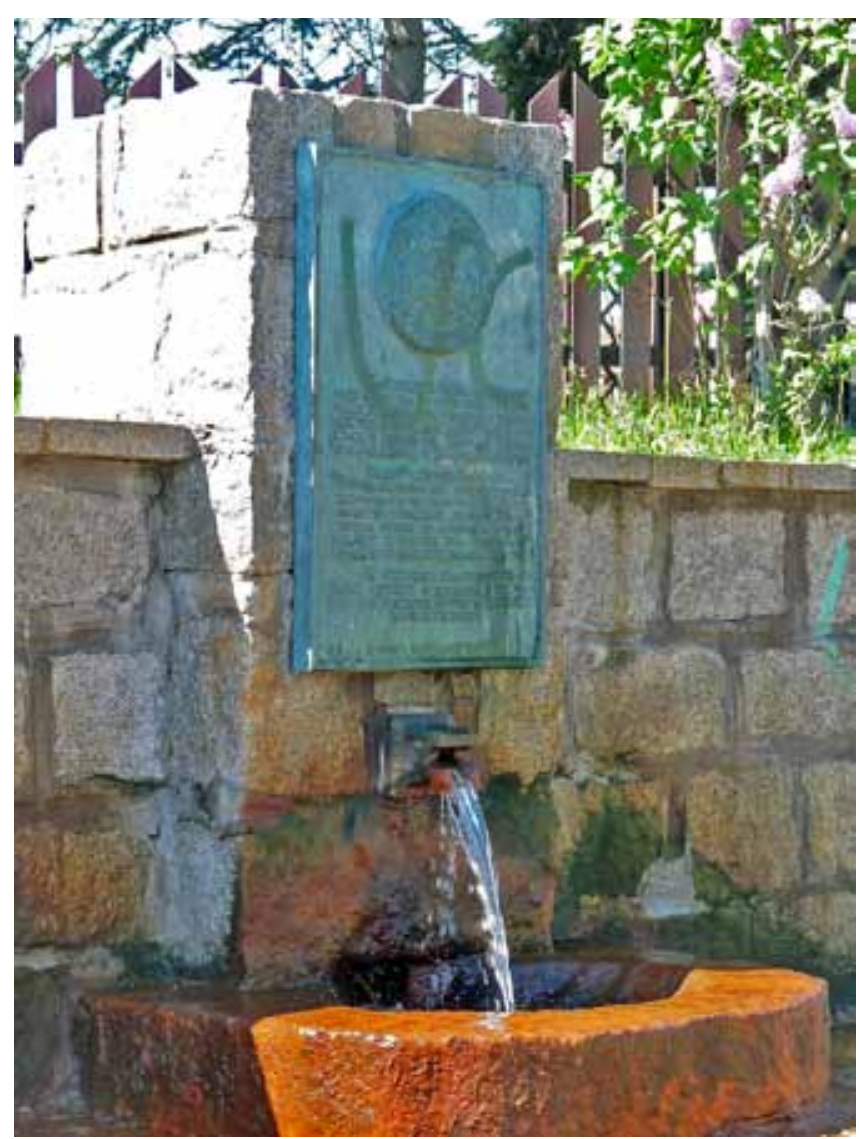

Fig. 5. Brine spring on Salt Isle in Kołobrzeg, phot. A. Krawiec • Źródło solankowe na Wyspie Solnej w Kołobrzegu, fot. A. Krawiec

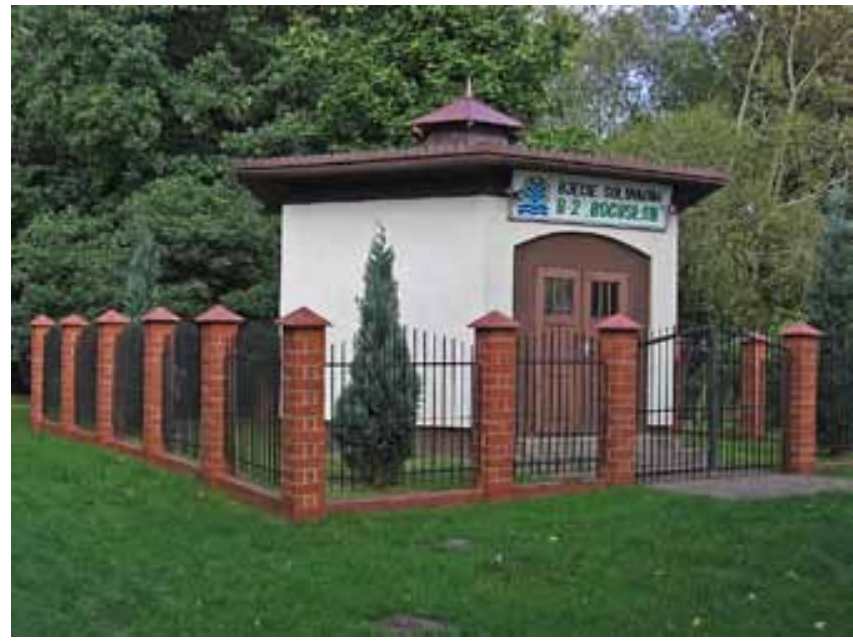

Fig.6. Brine well B-2 (Bogusław) in Kołobrzeg, phot. A. Krawiec - Ujęcie solanki B-2 (Bogusław) w Kołobrzegu, fot. A. Krawiec
The Precambrian platform is a diverse geological, structural and hydrogeological unit located in the north-eastern part of Poland. This is the area where the deposits of the crystalline basement are the shallowest in the Polish Lowlands and a significant reduction of the Mesozoic rocks is recorded. Generally, this province is poor in mineral, thermal and medicinal waters. Mineral waters of the Cl-Na type $\left(10-50 \mathrm{~g} / \mathrm{dm}^{3}\right)$ are found in the Mesozoic sediments of the Łeba Uplift and the Peribaltic Syneclise, and their salinity is linked to the Zechstein deposits. Within the Łeba Uplift water of the Cl$\mathrm{Na}$, I type of mineralisation $34.3 \mathrm{~g} / \mathrm{dm}^{3}$ extracted in Ustka from the Lower Permian sandstones and conglomerates were considered as therapeutic. Currently, these are not utilised. The main utilised aquifer in the Peribaltic Syneclise is that in the Lower Triassic sediments (Sopot, Gdańsk, Jastarnia, Krynica Morska). It is most frequently found at depths from 520 to $1,150 \mathrm{~m}$, and its waters' mineralisation is usually from 22 to $52 \mathrm{~g} / \mathrm{dm}^{3}$. Currently, based on $4.2 \%$ water of the $\mathrm{Cl}-\mathrm{Na}$, I type, the resort in Sopot operates, where the daily yield of brine is about $83 \mathrm{~m}^{3}$ (Fig. 3).

In the discussed area, within the Paleozoic platform, there are: Pomeranian Trough, Pomeranian Anticlinorium and Szczecin Trough (Fig. 2). Thick Zechstein saline series with salt structures are found here. Within this province chloridesodium waters dominate. Geological structure and fault tectonics contribute to the ascent of mineralised chloride waters which sometimes appear on the surface or near it. Such phenomena are known for example from the area of Kamien Pomorski and Kołobrzeg (Dowgiałło, 1965) where natural brine springs were the basis for the production of table salt. As early as in the $9^{\text {th }}$ c. Kołobrzeg was an important commercial centre trading salt obtained from salt-works based on brine springs. Around the mid $19^{\text {th }} \mathrm{c}$. treatment based on brine water was introduced in coastal bathing sites such as Kołobrzeg and Świnoujście.

The entire area of the Pomeranian Trough is dominated by chloride waters and the most important aquifers are found in the Lower Cretaceous and Jurassic sandstones. Within the Pomeranian Trough in the Lower Cretaceous strata the water mineralisation is usually a few to several $\mathrm{g} / \mathrm{dm}^{3}$ and the temperature is up to $30^{\circ} \mathrm{C}$. The Jurassic deposits mainly contain $\mathrm{Cl}-\mathrm{Na}$ waters. Mineralisation of these waters increases with depth (Fig. 2).

The presence of mineralised waters, which were used for refining salt and for therapeutic purposes, has been known in the area of the Pomeranian Anticlinorium for centuries. The main aquifer within the Mesozoic strata occurs in the Early Jurassic (Liassic) sandstone and is a reservoir of the pore type. Within the Pomeranian Anticlinorium medicinal waters are exploited in the spa towns of Kamień Pomorski and Kołobrzeg. Furthermore, therapeutic waters are found in Dziwnówek and Międzywodzie. In Kamień Pomorski and Kołobrzeg therapeutic peat is also exploited (Fig. 4).

Natural brine springs and halophytic vegetation in the vicinity of Kamień Pomorski have been known for a long time (Dowgiałło, 1965). In the years 1875-1881 a borehole $E d$ ward I was made in Kamień Pomorski, which was operated 


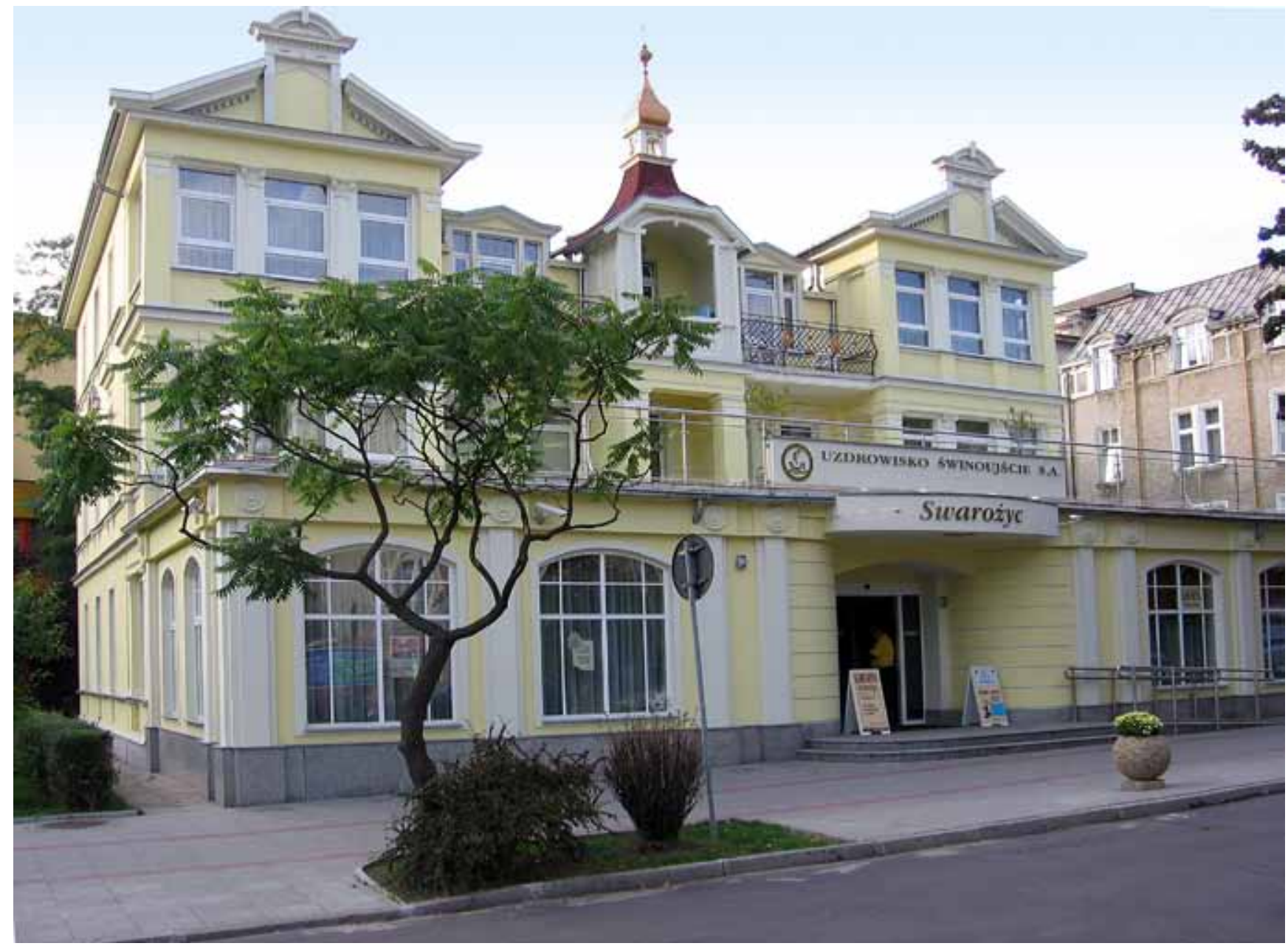

Fig. 7. Health resort in Świnoujście - Swarożyc spa complex, phot. A. Krawiec • Dom Zdrojowy Swarożyc w Świnoujściu, fot. A. Krawiec

by the health resort until the mid 1970s. Presently, the spa is supplied with Na-Cl, I brine of mineralisation $34.0 \mathrm{~g} / \mathrm{dm}^{3}$ from a new borehole Edward III. The spa also owes currently inactive wells Józef in Dziwnówek and Kamień Pomorski $I G-1$ in Międzywodzie. The borehole Józef in Dziwnówek exploits hypothermal $\left(21^{\circ} \mathrm{C}\right.$ at the free flow) $\mathrm{Cl}-\mathrm{Na}, \mathrm{I}, \mathrm{Fe}$ brine of mineralisation $66.6 \mathrm{~g} / \mathrm{dm}^{3}$ from the depth of 715.7$766.7 \mathrm{~m}$. The borehole Kamien Pomorski IG-1 extracts Cl$\mathrm{Na}$, I brine of mineralisation $93.6 \mathrm{~g} / \mathrm{dm}^{3}$ and temperature $14-18^{\circ} \mathrm{C}$ from the Muschelkalk and Keuper (depth of 977$1,053 \mathrm{~m}$ ) (Krawiec, 2002). From the borehole Wolin $I G-1$ in Międzyzdroje (now closed) from the Liassic layer at the depth 1,240-1,309 $\mathrm{m}, \mathrm{Cl}-\mathrm{Na}$ brine of the mineralisation of $174 \mathrm{~g} / \mathrm{dm}^{3}$ is extracted.

In the centre of Kołobrzeg, on the Salt Isle in the Parsęta Valley, there are brine springs No. 18 and 35 of mineralisation about $51 \mathrm{~g} / \mathrm{dm}^{3}$ (Fig. 5). Currently, in Kołobrzeg Cl-Na, $\mathrm{I}$ and $\mathrm{Cl}-\mathrm{Na}, \mathrm{I}, \mathrm{Fe}$ waters of mineralisation from 53 to $61 \mathrm{~g} / \mathrm{dm}^{3}$ are extracted from the boreholes Emilia, Warcisław and Anastazja as well as B-1 (Barnim) and B-2 (Bogustaw) (Fig. 6).

The most promising aquifers in the area of the Szczecin Synclinorium are those in the Cretaceous and Jurassic strata. These are mostly $\mathrm{Cl}-\mathrm{Na}$ waters of mineralisation from several to more than $100 \mathrm{~g} / \mathrm{dm}^{3}$. Mineralisation substantially increases from the limbs of the trough towards its axis and from the south to the north. In Świnoujście medicinal waters of the Cl-Na, I, Fe type are extracted from the Lower Cretaceous strata. Brine of mineralisation about $43-45 \mathrm{~g} / \mathrm{dm}^{3}$ is primarily drawn from the borehole Jantar, from the depth $227-237 \mathrm{~m}$. The brine with similar characteristics is also exploited in the German spa town of Heringsdorf located $7 \mathrm{~km}$ west of Świnoujście.

\section{The use of therapeutic waters}

Balneology uses the properties of waters and peat. A growing number of people benefit from preventive procedures in health resorts. Spa towns and sanatoria introduce modern forms of treatment. In recent years there has been a dynamic development of services such as spa and wellness; a wide range of such services is offered primarily by Sopot and Kołobrzeg.

Coastal resorts have naturopathy facilities, sanatoria houses, spa hospitals and health, and leisure centres. The medicinal profile of the coastal spa towns includes the following illnesses: orthopaedic-traumatic, neurological, rheumatological, cardiological (including hypertension), of upper and lower respiratory tract, endocrinological (including thyroid gland), dermatological, diabetes, osteoporosis and obesity (Ponikowska, 2007). 


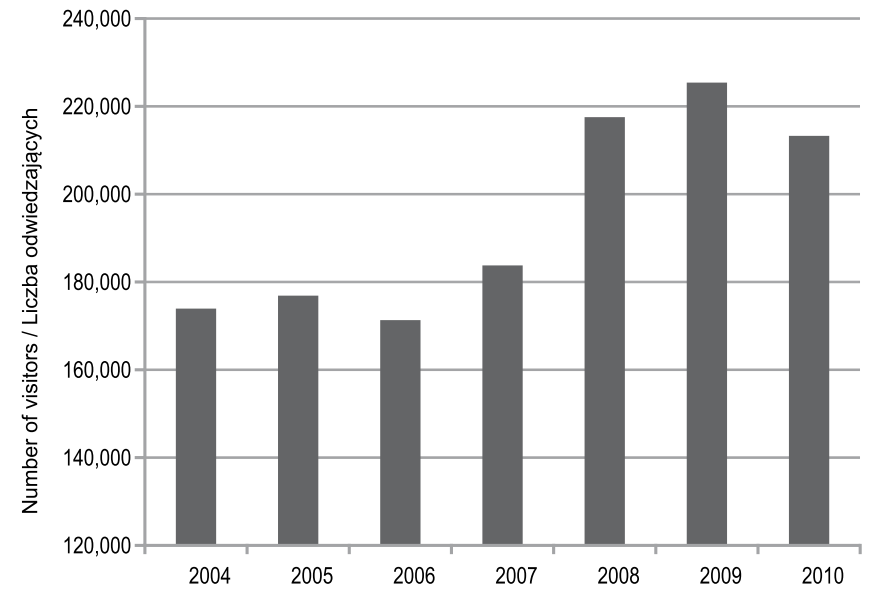

Currently, for medicinal and recreational purposes mineral Cl-Na waters from the intakes in Świnoujście, Kamień Pomorski, Kołobrzeg and Sopot are used (Tab. 1). Based on therapeutic waters, the performed treatments include brine baths and pool baths, as well as individual and group inhalations. In addition, common are: peat compresses and wraps, artificial mineral baths, hydrotherapy, underwater massage, physiotherapy, electro- and phototherapy, cryotherapy, thalassotherapy, and paraffin compresses.

Fig. 8. Number of visitors in health resorts in Western Pomeranian Voivodeship in 2004-2010 (based on Central Statistical Office - GUS) • Liczba odwiedzających uzdrowiska w województwie zachodniopomorskim w latach 2004-2010 (na podstawie danych GUS)

Tab. 2. Characteristic of therapeutic groundwater of the Polish Baltic Coast • Charakterystyka wód leczniczych polskiego wybrzeża Bałtyku

\begin{tabular}{|c|c|c|c|c|c|c|}
\hline \multirow{3}{*}{$\begin{array}{l}\text { Locality } \\
\text { miejscowość }\end{array}$} & \multirow{3}{*}{$\begin{array}{l}\text { Number of } \\
\text { intakes } \\
\text { / Depth } \\
\text { liczba ujęć / } \\
\text { głębokość } \\
\text { m }\end{array}$} & \multirow{3}{*}{$\begin{array}{c}\text { Lithology / Stratigraphy } \\
\text { litologia / stratygrafia }\end{array}$} & \multirow{3}{*}{$\begin{array}{c}\begin{array}{c}\text { Reserves** } \\
\text { zasoby } \\
\text { eksploatacyjne }\end{array} \\
\mathrm{m}^{3} / \mathrm{h}\end{array}$} & \multicolumn{3}{|c|}{ Characteristic of waters } \\
\hline & & & & $\begin{array}{c}\text { TDS } \\
\text { mineralizacja }\end{array}$ & $\begin{array}{l}\text { Chemical } \\
\text { type }\end{array}$ & $\begin{array}{l}\text { Temperature } \\
\text { temperatura }\end{array}$ \\
\hline & & & & $\mathrm{g} / \mathrm{dm}^{3}$ & chemiczny & ${ }^{\circ} \mathrm{C}$ \\
\hline \multicolumn{7}{|c|}{ Province A: Precambrian platform / Prowincja A: platforma prekambryjska } \\
\hline Sopot * & $\begin{array}{c}1 \\
839\end{array}$ & $\begin{array}{l}\text { sandstones } / \mathrm{T}_{1} \\
\text { piaskowce }\end{array}$ & 44.0 & 42.0 & $\mathrm{Cl}-\mathrm{Na}, \mathrm{I}$ & 18 \\
\hline Ustka * & $\begin{array}{c}1 \\
707\end{array}$ & $\begin{array}{c}\text { sandstones, } \\
\text { conglomerates / } \mathrm{P}_{1} \\
\text { piaskowce, zlepieńce }\end{array}$ & $\begin{array}{c}31.0 \\
\text { unexploited } \\
\text { nieeksploatowane }\end{array}$ & 34.3 & $\mathrm{Cl}-\mathrm{Na}, \mathrm{I}$ & 21 \\
\hline \multicolumn{7}{|c|}{ Province B - Paleozoic platform / Prowincja B: platforma paleozoiczna } \\
\hline \multirow{3}{*}{ Kołobrzeg * } & \multirow{3}{*}{$\begin{array}{c}7 \\
42-354\end{array}$} & $\begin{array}{l}\text { sands / Q } \\
\text { piaski }\end{array}$ & \multirow{3}{*}{98.52} & 1.6 & $\mathrm{Cl}-\mathrm{HCO}_{3}-\mathrm{Na}$ & $8-12$ \\
\hline & & $\begin{array}{l}\text { sands, sandstones / } J_{2} \\
\text { piaski, piaskowce }\end{array}$ & & $53.0-60.0$ & $\mathrm{Cl}-\mathrm{Na}, \mathrm{I}$ & \\
\hline & & $\begin{array}{l}\text { sandstones / } \mathrm{J}_{1} \\
\text { piaskowce }\end{array}$ & & $60.0-61.0$ & $\mathrm{Cl}-\mathrm{Na}, \mathrm{I}, \mathrm{Fe}$ & \\
\hline $\begin{array}{l}\text { Kamień } \\
\text { Pomorski * }\end{array}$ & $\begin{array}{c}1 \\
400\end{array}$ & $\begin{array}{l}\text { sandstones / J } \\
\text { piaskowce }\end{array}$ & 15.0 & 34.0 & $\mathrm{Cl}-\mathrm{Na}, \mathrm{I}$ & 16 \\
\hline Dziwnówek & $\begin{array}{c}1 \\
790\end{array}$ & $\begin{array}{l}\text { sandstones / J } \\
\text { piaskowce }\end{array}$ & $\begin{array}{c}30.0 \\
\text { unexploited } \\
\text { nieeksploatowane }\end{array}$ & 66.6 & $\mathrm{Cl}-\mathrm{Na}, \mathrm{I}, \mathrm{Fe}$ & 21 \\
\hline Międzywodzie & $\begin{array}{c}1 \\
1053\end{array}$ & $\begin{array}{c}\text { sandstones, marls, } \\
\text { limestones } / \mathrm{T}_{2-3} \\
\text { piaskowce, margle, } \\
\text { wapienie }\end{array}$ & $\begin{array}{c}1.4 \\
\text { unexploited } \\
\text { nieeksploatowane }\end{array}$ & 9.36 & $\mathrm{Cl}-\mathrm{Na}, \mathrm{I}, \mathrm{Fe}$ & $14-18$ \\
\hline Świnoujście * & $\begin{array}{c}3 \\
240-275\end{array}$ & $\begin{array}{l}\text { sands / } \mathrm{K}_{1} \\
\text { piaski }\end{array}$ & 23.8 & $43.0-45.0$ & $\begin{array}{c}\mathrm{Cl}-\mathrm{Na}, \mathrm{I}, \mathrm{Fe} \\
\mathrm{Cl}-\mathrm{Na}, \mathrm{I}\end{array}$ & 15 \\
\hline
\end{tabular}

* - developed deposits / złoża zagospodarowane (objęte koncesją na eksploatację)

** - Resources/reserves after Polish Geological Institute - National Research Institute, 2011 / zasoby wg Państwowego Instytutu Geologicznego - Państwowego Instytutu Badawczego, 2011 
Besides medicinal values, health resorts located in the coastal area show tourist value. July and August are dominated by leisure and recreation functions, while the spa function is only complementary. This type of interdependences, described by Słomka and Kicińska (2009), are also known from the mountain regions, such as the area of Krynica.

In the area of the Kołobrzeg health resort water Jantar of the $\mathrm{Cl}-\mathrm{HCO}_{3}-\mathrm{Na}-\mathrm{Ca}$ type and mineralisation of $0.82 \mathrm{~g} / \mathrm{dm}^{3}$ is bottled. few years ago the production of mineral water of the $\mathrm{Cl}-\mathrm{HCO}_{3}-\mathrm{Na}$ type and the mineralisation of $1.6 \mathrm{~g} / \mathrm{dm}^{3} \mathrm{known}$ as 'The Pearl of the Baltic' has ended. These intakes extract the water from Quaternary deposits, from the depth of approximately $40 \mathrm{~m}$.

\section{Spa tourism}

Over the past several years a growing interest in spa tourism, which is identified as a recreational visits to spas, has been observed. During such a stay, often having a prophylactic nature, for the regeneration of the body natural factors, such as water and climate, are used. This type of tourism combines holiday with a stay intended to improve health. It is, therefore, essential to combine functions typical for a spa town which has facilities for treatment and accommodation, with the functions of a place which offers active recreation and participation in cultural and entertainment events.

Important attractions for health tourism primarily include natural environment such as natural resources, climate and landscape, as well as cultural and social attractions located in the area. The quality and attractiveness of stay is also influenced by tourist infrastructure, treatment (therapeutic) facilities, accommodation and catering.

Growing spa tourism contributes to increased economic development of a given town. This results in faster growth and modernisation of the hotel and therapeutic base of a spa. Increasing number of health resort visitors also affects the number of issued treatments, and, thus, the intensity with which the natural resources, such as medicinal water and therapeutic peat, are used. In the study area there are excellent climatic conditions and rich deposits of mineral waters, and peloids. Świnoujście as well as Kołobrzeg, Sopot and Kamień Pomorski have rich facility base for recreation and medicinal treatment, and are important centres for domestic and foreign tourism (Chowaniec, Zuber, 2008). These towns have a rich history preserved in monuments of the old infrastructure and spa architecture.

Świnoujście is proud of its spa park, which is a 'nature monument', and the coastal spa quarter with buildings from the late $19^{\text {th }}$ and early $20^{\text {th }}$ c. (Fig. 7). An important attraction of the spa town are magnificent coastal beaches.

Kamień Pomorski is one of the oldest towns in Western Pomerania. There are a number of historical monuments here, such as the Romanesque-Gothic cathedral with its famous baroque organs, the Gothic town hall, the Episcopal manor house and the defensive walls with the Wolin Gate. Between Świnoujście and Kamień Pomorski the Wolin National Park is located with the highest cliff shore in Poland and nature reserves with unique flora and fauna. In Wapnica there is an interesting geotourist object the Turquoise Lake formed in a former chalk pit.

Kołobrzeg is also one of the oldest towns in Pomerania; it has already existed in the 8th c. when a stronghold functioned there. Kołobrzeg was the centre of salt production, trade and fishing. There are numerous valuable monuments there, including the basilica, fort, i.e. the remains of an ancient fortress, the town hall, water tower and a lighthouse. The spa district has a coastal park with a promenade and a pier $220 \mathrm{~m}$ long.

In Sopot the attraction of the spa town is raised by villas, guest houses and spa houses built in the 19th and early 20th c. Best known objects include the Grand Hotel, the Forest Opera and the horse racecourse. Sopot has a pier - one of the longest in Europe and the longest in Poland (over $500 \mathrm{~m}$ long). It is a wooden construction, which connects to the Resort Square and the Spa Square.

What deserves attention in Ustka is the promenade surrounded by historic villa and hotel buildings, old town with a number of fishing huts, neo-Gothic church and a lighthouse. Nearby Ustka the Słowiński National Park is located with the largest complex of migrating dunes in Central Europe.

What should be emphasised while analysing the data concerning tourism in spa facilities is the average length of stay, which is over 12 days. These are mostly long-term stays. The analysis of the use of accommodation in spa facilities demonstrates that it is much higher than in other tourist facilities on the coast and exceeds $71 \%$ (Sawińska, 2009). The number of people using spa facilities is gradually increasing. In 2008-2010 this number for spas in Western Pomerania exceeded 210,000 visitors (Fig. 8) and the effectiveness of accommodation capacity reached $80 \%$.

In 2008 Kołobrzeg, which is the largest seaside resort in Poland, accommodated nearly 250,000 people, of which over $35 \%$ were foreign visitors.

\section{Conclusions}

Brine springs and increased ascent of brines from the substrate (Kołobrzeg and Kamień Pomorski), and easy access to the deposits of peloids, i.e. peat (deposits of medicinal peat in Kamień Pomorski, Kołobrzeg, Ustka, Dąbki), known for centuries, had a major impact on the development of spa towns. The oldest health resorts found in the coastal area were based upon brines, from which for more than 1000 years salt has been refined (Kołobrzeg). This area is dominated by waters of the $\mathrm{Cl}-\mathrm{Na}$ type, and among the specific components of pharmacodynamic relevance iodides and sometimes iron are dominant. In this region there are also a number of medicinal peat deposits documented in Kamień Pomorski, Kołobrzeg, Ustka and Dąbki.

Cl-Na waters which occur in the area, in spite of their healing properties, are still not fully exploited. The operating boreholes in Kamień Pomorski, Kołobrzeg, Sopot and Świnoujście draw only a small percentage of the confirmed resources (Tab. 2). The wells existing in Dziwnówek, Międzywodzie, Międzyzdroje, Ustka and Krynica Morska or in the vicinity of Mielno-Ustronie Morskie are still not used. 
In this area there is, therefore, a great potential for wider use of the therapeutic waters from the already used resources or from those presently in disused mineral water intakes.

The towns where naturopathy health centres operate benefit from centuries of tradition of travelling "to the waters". As studies demonstrate (Sawińska, 2009), the accommodation base in such localities is much better exploited through- out the year. In typical holiday destinations, the use of tourist facilities is mostly limited to the two summer months (July and August), while in health resorts a significant part of such objects operates year-round. Moreover, Polish seaside health resorts accept a growing percentage of foreign tourists (mostly from Germany and Sweden), which is particularly evident in Świnoujście, Kamień Pomorski and Kołobrzeg. $\square$

\section{Streszczenie}

\section{Wody lecznicze jako walory geoturystyczne polskiego wybrzeża Bałtyku Arkadiusz Krawiec}

\section{Wstęp}

Na obszarze Polski znajdują się 44 miejscowości mające status uzdrowiska. Sześć z nich położonych jest w strefie wybrzeża Morza Bałtyckiego. Są to: Świnoujście, Kamień Pomorski, Kołobrzeg i Dąbki znajdujące się na terenie województwa zachodniopomorskiego oraz Ustka i Sopot w województwie pomorskim (Fig. 1). Na ich powstanie i lokalizację wpływ miało występowanie złóż naturalnych surowców leczniczych (solanki, borowiny) oraz lecznicze właściwości klimatu nadmorskiego.

Za lecznicze uważa się niezanieczyszczone pod względem chemicznym i mikrobiologicznym wody podziemne o naturalnej zmienności cech fizycznych i chemicznych. Każda woda mineralna (o mineralizacji $\geq 1 \mathrm{~g} / \mathrm{dm}^{3}$ ) może być wodą leczniczą, bez względu na to czy zawiera składniki swoiste (Rozporządzenie..., 2006). Za leczniczą może być uznana także woda słabo zmineralizowana, zawierająca co najmniej jeden składnik swoisty i/lub charakteryzująca się temperaturą powyżej $200^{\circ} \mathrm{C}$ (Tab. 1).

Do solanek zaliczamy wody o mineralizacji ogólnej wynoszącej co najmniej $35 \mathrm{~g} / \mathrm{dm}^{3}$, której głównymi składnikami są jony: chlorkowy, sodowy i wapniowy. Największe zasoby tych wód w Polsce znajdują się na terenie Niżu Polskiego. Wody te są dobrze rozpoznane i zbadane pod względem chemicznym. Solanki są powszechnie wykorzystywane w balneologii w większości uzdrowisk położonych na obszarze Niżu Polskiego.

Celem pracy jest przedstawienie warunków występowania i możliwości wykorzystania wód leczniczych na polskim wybrzeżu Morza Bałtyckiego. W pracy omówiono główne walory turystyczne miejscowości uzdrowiskowych na tym obszarze oraz przedstawiono możliwość wykorzystania wód leczniczych dla rozwoju turystyki uzdrowiskowej.

\section{Budowa geologiczna i warunki hydrogeologiczne}

Strefa polskiego wybrzeża Bałtyku położona jest na obszarze Niżu Polskiego, gdzie wody lecznicze i termalne występują w obrębie dwóch dużych regionów wód mineralnych, tj. prowincji platformy paleozoicznej oraz prowincji platformy prekambryjskiej (Paczyński, Płochniewski, 1996). Wody mineralne na analizowanym obszarze występują na różnych głębokościach. Wody uznane za lecznicze stwierdzono głównie w osadach kredy, jury oraz triasu (Fig. 2). Wody mine- ralne występują także powszechnie w starszych piętrach wodonośnych. Budowa geologiczna i tektonika uskokowa przyczyniają się do ascenzji zmineralizowanych wód chlorkowych, które niekiedy pojawiają się na powierzchni lub w jej pobliżu. Zjawiska takie znane są np. z rejonu Kamienia Pomorskiego czy Kołobrzegu (Fig. 5; Dowgiałło, 1965). Naturalne wypływy źródeł solankowych stanowiły tam podstawę do produkcji soli kuchennej. Już w IX w. Kołobrzeg był ważnym ośrodkiem handlu solą uzyskiwaną z warzelni, do których wykorzystywano źródła solankowe. Około połowy XIX w. rozpoczął się rozwój lecznictwa opartego na solankach. Zaczęły one być wykorzystywane w kąpieliskach nadmorskich, jak Kołobrzeg czy Świnoujście.

Prowincja platformy prekambryjskiej jest uboga w wody mineralne, termalne i lecznicze. Wody mineralne typu Cl-Na $\left(10-50 \mathrm{~g} / \mathrm{dm}^{3}\right)$ w utworach mezozoicznych występują w obrębie wyniesienia Łeby i obniżenia perybałtyckiego, a ich zasolenie związane jest z osadami cechsztynu. W obrębie wyniesienia Łeby za lecznicze zostały uznane wody typu $\mathrm{Cl}-$ $\mathrm{Na}, \mathrm{J}$ o mineralizacji $34,3 \mathrm{~g} / \mathrm{dm}^{3} \mathrm{z}$ piaskowców i zlepieńców permu dolnego w Ustce. Obecnie nie są one użytkowane. W obniżeniu perybałtyckim w oparciu o 4,2-procentową wodę typu Cl-Na, J działa Uzdrowisko Sopot, gdzie dziennie pobiera się około $83 \mathrm{~m}^{3}$ solanki (Fig. 3).

W obrębie platformy paleozoicznej dominują wody chlorkowo-sodowe. Na obszarze niecki pomorskiej za najważniejsze uznać należy poziomy wodonośne w piaskowcach kredy dolnej i jury. W obrębie warstw kredy dolnej wody mają najczęściej mineralizację kilku - kilkunastu gram na decymetr sześcienny i temperaturę do $30^{\circ} \mathrm{C}$. Mineralizacja tych wód wzrasta wraz z głębokością (Fig. 2).

Występowanie wód zmineralizowanych, które wykorzystywane były do warzenia soli i do celów leczniczych na obszarze antyklinorium pomorskiego znane jest od wieków. Główny poziom wodonośny występuje w piaskowcach liasu i z niego są eksploatowane wody lecznicze w uzdrowiskach Kamień Pomorski i Kołobrzeg. Ponadto wody lecznicze występują w miejscowościach Dziwnówek i Międzywodzie. W Kamieniu Pomorskim i Kołobrzegu eksploatuje się także do celów leczniczych borowinę (Fig. 4).

Obecnie Uzdrowisko Kamień Pomorski zaopatrywane jest w solankę Na-Cl, J o mineralizacji $34,0 \mathrm{~g} / \mathrm{dm}^{3}$ z odwiertu „Edward III”. Uzdrowisko dysponuje także nieczynnymi obecnie odwiertami „Józef” w Dziwnówku i „Kamień Pomorski IG-1” w Międzywodziu. Otworem „Józef” w Dziwnówku z głębokości 715,7-766,7 m ujęto hipotermalną (o temperaturze $21^{\circ} \mathrm{C}$ przy swobodnym wypływie wody) solankę Cl-Na, J, Fe o mineralizacji $66,6 \mathrm{~g} / \mathrm{dm}^{3}$. Z ujęcia Kamień Pomorski 
IG-1, z warstw wapienia muszlowego oraz kajpru (głęb. 977-1053 m) można pobierać solankę Cl-Na, J o mineralizacji $93,6 \mathrm{~g} / \mathrm{dm}^{3}$ i temperaturze $14-18^{\circ} \mathrm{C}$ (Krawiec, 2002). W Międzyzdrojach $\mathrm{z}$ otworu Wolin IG-1 (obecnie nieczynny) z warstw liasu, z głębokości 1240-1309 m, można pozyskać wodę typu Cl-Na o mineralizacji $174 \mathrm{~g} / \mathrm{dm}^{3}$.

W centrum Kołobrzegu, w dolinie Parsęty, na Wyspie Solnej znajdują się źródła solankowe nr 18 i 35 o mineralizacji około $51 \mathrm{~g} / \mathrm{dm}^{3}$ (Fig. 5). Obecnie w Kołobrzegu do celów leczniczych wykorzystuje się wody Cl-Na, J oraz Cl-Na, J, Fe o mineralizacji od 53 do $61 \mathrm{~g} / \mathrm{dm}^{3} \mathrm{z}$ ujęć: „Emilia”, „Warcisław”, „Anastazja” oraz B-1 („Barnim”) i B-2 (,Bogusław") (Fig. 6).

Na obszarze synklinorium szczecińskiego za najbardziej perspektywiczne uznawane są poziomy wodonośne w obrębie warstw kredy i jury. Występują tutaj przeważnie wody typu Cl-Na o mineralizacji od kilku do ponad $100 \mathrm{~g} / \mathrm{dm}^{3}$. Mineralizacja wzrasta od skrzydeł niecki w kierunku jej osi oraz z południa na północ. W Świnoujściu z warstw kredy dolnej eksploatowane są wody lecznicze typu $\mathrm{Cl}-\mathrm{Na}, \mathrm{J}, \mathrm{Fe}$ o mineralizacji około $43-45 \mathrm{~g} / \mathrm{dm}^{3}$.

\section{Wykorzystanie wód leczniczych}

Balneologia wykorzystuje właściwości wód (Fig. 3, Fig. 6) oraz borowin (Fig. 4). Do miejscowości uzdrowiskowych przyjeżdża coraz więcej osób korzystających z zabiegów o charakterze profilaktycznym. Coraz częściej wprowadza się nowoczesne formy leczenia, dynamicznie rozwijają się usługi typu spa i wellness, a bogatą ofertę tego typu usług oferuje głównie Sopot i Kołobrzeg. W nadmorskich miejscowościach uzdrowiskowych działają zakłady przyrodolecznicze, sanatoria i szpitale uzdrowiskowe oraz ośrodki leczniczo-wypoczynkowe. Profil leczniczy obejmuje głównie: choroby ortopedyczno-urazowe, układu nerwowego, reumatologiczne, kardiologiczne (w tym nadciśnienie), górnych i dolnych dróg oddechowych, endokrynologiczne (w tym tarczycy), skóry, cukrzycę, osteoporozę i otyłość (Ponikowska, 2007).

W miejscowościach uzdrowiskowych położonych w obszarze nadmorskim, oprócz walorów leczniczych (zdrowotnych) bardzo ważną rolę odgrywają także walory turystyczne. Szczególnie w okresie lipca i sierpnia dominuje tutaj funkcja wypoczynkowa i rekreacyjna, którą wówczas uzupełnia funkcja uzdrowiskowa. W ciągu ostatnich kilku lat obserwuje się wzrost zainteresowania turystyką uzdrowiskową, która jest identyfikowana jako wyjazdy wypoczynkowe do miejscowości uzdrowiskowych. Podczas takiego pobytu, mającego często charakter profilaktyczny, do regeneracji or- ganizmu wykorzystuje się czynniki naturalne takie jak woda czy klimat. Ten rodzaj turystyki łączy wypoczynek z pobytem mającym na celu polepszenie stanu zdrowia. Niezbędne jest zatem połączenie typowych funkcji uzdrowiska dysponującego bazą zabiegową i noclegową z funkcjami miejscowości oferującej możliwość aktywnego wypoczynku, uczestniczenia w imprezach o charakterze kulturalnym czy rozrywkowym.

Rozwój turystyki uzdrowiskowej przyczynia się do większego rozwoju gospodarczego danej miejscowości. Dzięki temu następuje szybsza rozbudowa i modernizacja bazy zabiegowej i hotelowej. Zwiększenie liczby kuracjuszy wpływa również na liczbę świadczonych zabiegów, a tym samym na intensywność wykorzystania zasobów wód leczniczych czy borowin. Na rozpatrywanym obszarze występują doskonałe warunki klimatyczne oraz bogate złoża wód leczniczych i peloidów. Zarówno Świnoujście, jak i Kołobrzeg, Sopot czy Kamień Pomorski dysponują bogatą bazą wypoczynkowo-leczniczą i są ważnymi ośrodkami turystyki krajowej i zagranicznej. Miejscowości te mają bogatą historię, o której świadczą zabytki starej infrastruktury i architektury zdrojowej.

Występujące na tym obszarze wody typu Cl-Na, mimo swych leczniczych właściwości nadal nie są w pełni wykorzystywane. Eksploatowane ujęcia w Kamieniu Pomorskim, Kołobrzegu, Świnoujściu czy Sopocie pobierają zaledwie kilka procent zatwierdzonych zasobów eksploatacyjnych (Tab. 2). Dalej nie są wykorzystane istniejące ujęcia w Dziwnówku, Międzywodziu, Międzyzdrojach, Ustce, Krynicy Morskiej czy też w rejonie Mielno-Ustronie Morskie. Na obszarze tym występują zatem duże możliwości szerszego wykorzystania istniejących zasobów wód leczniczych lub też uruchomienia istniejących, a obecnie nieczynnych ujęć wód mineralnych.

Miejscowości, w których funkcjonują przyrodolecznicze zakłady uzdrowiskowe, korzystają z wielowiekowej tradycji wyjazdu „do wód”. Jak wykazują badania (Sawińska, 2009) w miejscowościach tych baza noclegowa jest w znacznie lepiej wykorzystana w ciągu całego roku. W miejscowościach typowo wypoczynkowych obciążenie i działalność obiektów turystycznych sprowadza się głównie do dwóch miesięcy letnich (lipiec i sierpień), natomiast tam gdzie działają zakłady lecznictwa uzdrowiskowego znaczna część tych obiektów ma charakter całoroczny. W nadmorskich miejscowościach uzdrowiskowych coraz większy jest także procentowy udział turystów z zagranicy (głównie z Niemiec i Szwecji), co szczególnie widoczne jest w Świnoujściu, Sopocie, Kołobrzegu czy Kamieniu Pomorskim.

\section{References (Literatura)}

Chowaniec, J., Zuber, A., 2008. Touristic geoattractions of Polish Spas. Przeglad Geologiczny, 56: 706-711.

Ciężkowski, W., Chowaniec, J., Górecki, W., Krawiec, A., Rajchel, L., Zuber, A., 2010. Mineral and thermal waters of Poland. Przeglad Geologiczny, 58: 762-774.

Dowgiałło J., 1965. Solanki Pomorza Zachodniego. Szczecińskie Towarzystwo Naukowe, Szczecin.

Kaczor, D., 2006. The salinity of groundwater in Mesozoic and Cenozoic aquifers of NW Poland - origin and evolution. In: Hydrogeology and hydrogeochemistry (ed J. Dowgiałło), cz. II. Studia Geologica Polonica, 126: 5-76.

Kolago, C., 1964. Wody mineralne województwa szczecińskiego i perspektywy ich wykorzystania. Przeglad Zachodnio-Pomorski, 5: 65-85.

Krawiec, A., 2002. Studium hydrogeologiczne wód leczniczych antyklinorium kujawsko-pomorskiego (PhD dissertation). Arch. UMK. Toruń.

Paczyński, B., Płochniewski, Z., 1996. Wody mineralne i lecznicze Polski. Państw. Inst. Geol. Warszawa.

Ponikowska, I., 2007. Kompendium balneologii. Wyd. A. Marszałek. 
Rozporządzenie Rady Ministrów z dnia 14 lutego 2006 r. w sprawie złóż wód podziemnych zaliczonych do solanek, wód leczniczych i termalnych oraz złóż innych kopalin leczniczych, a także zaliczenia kopalin pospolitych z określonych złóż lub jednostek geologicznych do kopalin podstawowych. (Dz.U. 2006 Nr 32, poz. 220, z późniejszymi zmianami).
Sawińska, A. 2009. Produkt turystyki uzdrowiskowej jako markowy produkt turystyczny województwa zachodniopomorskiego. Ekonomiczne problemy turystyki, Uniw. Szczec., 567: 301-312.

Słomka, T., Kicińska, A., 2009. Turystyka uzdrowiskowa i rekreacja jako podstawa nowoczesnego produktu uzdrowiskowego. XVIII Kongres Uzdrowisk Polskich, Muszyna, 161-165. 